\title{
Agricultural utilisation of municipal sludge in willow plantation
}

\author{
Feliks Stachowicz'1,a, Tomasz Trzepieciński ${ }^{1}$, Marta Wójcik ${ }^{1}$, Adam Masłoń2, Witold Niemiec ${ }^{3}$ and Adam Piech ${ }^{3}$ \\ ${ }^{1}$ Rzeszow University of Technology, Department of Materials Forming and Processing, Al. Powst. Warszawy 8, 35-959 Rzeszów, Poland \\ ${ }^{2}$ Rzeszow University of Technology, Department of Chemistry and Environmental Engineering, Al. Powst. Warszawy 6, 35-959 Rzeszów, \\ Poland \\ ${ }^{3}$ Rzeszow University of Technology, Department of Water Purification and Protection, Al. Powst. Warszawy 6, 35-959 Rzeszów, Poland
}

\begin{abstract}
This paper presents the results of analyses of the monitoring selected energetic willow plantations ( 30 ha) located in Podkarpackie Province (Poland), which have been fertilised using a prototype trailer for land-applying municipal sludge. The fertilisation of the willow plantation is undertaken using this prototype for the subsurface application of municipal sewage sludge into soil. The presented prototype is a component of technology of energetic plant production that has been developed at the Rzeszow University of Technology. The results of soil investigations allow to us conclude that the deposition of sewage sludge using the presented prototype of the agricultural trailer is conducted in accordance with legal regulations and does not cause significant perturbation of the natural trophic chain.
\end{abstract}

\section{Introduction}

Recycling sewage sludge to agricultural land to benefit from essential plant nutrients and organic matter it contains, is regarded as an environmentally sustainable approach to managing the sludge generated from sewagetreatment plants [1]. Sewage sludge containing more than $54.2 \%$ organic matter can be treated as "organic fertilisers" [2].

During 2010 in Poland, the total amount of produced sewage sludge was $413-450$ thousand $\mathrm{Mg}$ [3]. It is worth highlighting that the amount of sludge generated in industrial treatment plants decreases from year to year, while the amount of municipal sewage sludge is increasing [4]. The dominant amount of sewage sludge is still stored (about 35\%), then about $29 \%$ is used for reclamation of land; only $2.6 \%$ is designed for fertilisation of plants that are used to produce compost [5]. The utilisation of sewage sludge for fertilisation of agricultural land is the most economic option for inland treatment plants, and is also widely practised in Poland $[4,6]$.

The use of organic waste in agriculture can improve the soil's productive capacity, and physical and chemical characteristics [7-9]. However, the main problems of an excessive application of sewage sludge are plant toxicity due to accumulation of heavy metals in soils [10] but also an increase in its salt content [11].

To grow properly perennial energy plants (with different structures and different root systems), a sufficient amount of nutrients is required, which for a long period during the establishment of plantation cannot be delivered to the soil in sufficient quantities

\footnotetext{
${ }^{a}$ Corresponding author: stafel@prz.edu.pl
}

$[12,13]$. Willow shoots are characterised by small concentrations of nitrogen and heavy metals, and using it is less harmful compared to coal combustion $[14,15]$. Energy plant plantations are mainly fertilised with mineral fertilisers using well-known specialised machines called fertiliser spreaders. The cultivation of energy plants such as e.g. Salix viminalis on fields fertilised with sewage sludge is becoming more and more popular in Poland [16]. Willow plants may be used to extract heavy metals from contaminated soils due to their tolerance to specific heavy metals and adaptation to soil [2]. Salix clones with high-metal accumulating capacity in the shoots may be suitable for phytoextraction of moderately contaminated sites [2, 17]. Willows can thus be used to remove from soil many heavy metals, especially cadmium $[18,19]$. The average content of phosphorus in sewage sludge is about $3 \%$ of dry mass and is also characterised by small amounts of potassium and calcium [20]. Gondek and Filipek-Mazur [21] claimed that sewage sludge particularly affects the increase in the content of calcium in plants, but this was not confirmed in [5]. According to Sieciechowicz et al. [16], it has not been confirmed that the fertilisation of plantations with sewage sludge exerts a significant impact on the accumulation of lead in the Salix viminalis biomass. The use of phosphorus by plants in the first year totals $20 \%$ and increases in succeeding years [22].

The application of granulated sludge from a sewagetreatment plant in a willow plantation resulted in biomass yields as high as $45 \mathrm{Mg} / \mathrm{ha} /$ year, compared to $15-20$ $\mathrm{t} / \mathrm{ha} /$ year without sludge fertilisation [23]. Lazdina et al. [17] found that, in the first season, the dry mass of control plantations without sewage was $0.2-0.6 \mathrm{Mg} / \mathrm{ha}$, 
but in the second season after fertilisation with sewage sludge of $14 \mathrm{Mg} / \mathrm{ha}$ ( $700 \mathrm{~kg}$ of nitrogen per ha), the dry mass of shoots reached 4.6-5.5 Mg/ha.

In this paper, a prototype of a trailer for land-applying municipal sludge is presented. Furthermore, the results of analyses of the monitoring of selected energetic willow plantations (30 ha) located in the Podkarpackie Province (Poland), which have been fertilised using sewage sludge, are presented.

\section{Agricultural use of sewage sludge}

The agronomical value of municipal sewage sludge depends on the content of pathogen microorganisms, heavy metals and certain organic compounds [24]. Whilst the pathogens can be removed by treatment to obtain a well-conditioned product, the organic compounds have to be monitored both with respect to their content and to their possible transfer to the soil and living beings [25]. The sustainability of sewage sludge agricultural disposal requires a value judgment based on knowledge and evaluation of the level of pollution of both sewage sludge and soil [24]. Sewage sludge contains significant amounts of nitrogen and phosphorus, and has value as an effective organic fertiliser [26, 27]. Sewage sludge application to soil also conserves organic matter.

The use of sewage sludge management in agriculture or for reclamation is characterized by the lowest costs ranging from 300-400 PLN per $1 \mathrm{Mg}$ of sludge. In contrast, combustion and co-combustion of sewage sludge are more expensive, even fivefold (Table 1) [28].

Table 1. Predicted costs of sewage sludge management using different methods.

\begin{tabular}{|c|c|}
\hline $\begin{array}{c}\text { Ways of sewage sludge } \\
\text { utilization }\end{array}$ & $\begin{array}{c}\text { Dis pos al cost of 1 Mg sewage } \\
\text { sludge [PLN] }\end{array}$ \\
\hline agricultural utilization & 300 \\
\hline composting & 600 \\
\hline combustion & 1500 \\
\hline co-combustion & 1750 \\
\hline
\end{tabular}

Agricultural use of sludge is regulated specifically by: - The Council Directive 86/278/EEC of 12 June 1986 on the Protection of the Environment, and in particular of the soil, when sewage sludge in used in agriculture,

- The Council Directive 91/676/EEC of 12 December 1991 concerning the protection of waters against pollution caused by nitrates from agricultural sources,

- Act on waste materials, of 14 December 2012 (J. of Laws, 2013, item 21),

- Regulation of Minister of Environment on communal sludge of 6 February 2015 (J. of Laws, 2015, item 257), which unified environmental standards for recycling sludge on farmland across the EU.

Sewage sludge may be considered as an important biological resource for sustainable agriculture. The major plant nutrients as nitrogen, phosphorus and potassium in municipal sewage sludges are not substantially removed during sludge processing; therefore the nutrients could improve the soil's nutritional status after sludge application [29]. Sludge also contains essential plant micronutrients such as boron, copper, manganese and zinc. Crops can accumulate toxic elements from sludgeamended soils; where heavily contaminated sludges and excessive rates of application are used, plants may accumulate concentrations that are phytotoxic [30]. In the case of application of sewage sludge in energetic plant plantations, the accumulation of heavy metals does not create health responses to humans, because they are not a part of the human trophic chain. The investigations of Smith and Vasiloudis [31] and Trinidade et al. [32] have shown that the yield of many plant species increases following the application of sewage sludge, which was connected to the increased supply of nutrients as a result of sludge application. After sludge application, the kind of a clone of energetic plant has an impact on the soil quality. The application of sewage sludge causes acidification of soil and increasing bioavailability of metals. The soil quality after sludge application depends on the kind of energetic plants due to different accumulation of heavy metals in tissues. Furthermore, the sewage sludge influences an increase of the calorific value of biomass, especially in the case of miscanthus and reed canary grass.

The analysis conducted by Labrecque et al. [33] showed that willow reacts in a linear increase of yield, to increase doses of sludge, expressed as assimilable nitrogen in $\mathrm{kg}$ per ha. A sample fertilized with sludge at the dose equivalent of solid $200 \mathrm{~kg}$ of nitrogen per ha, in comparison with a control, obtained following increments: $70 \%$ of height of the plants, $72 \%$ of the diameter, $415 \%$ by weight of shoots, $200 \%$ of root mass, $5-40 \%$ by weight of the leaves.

Taking into consideration the report of the EEA (European Environment Agency) [34], the total energy of potential of biomass produced in Poland will be 33 megatons of oil equivalent (MtOE) of which $73 \%$ will come from biomass crops in year 2020. An increase to 39 MtOE, with 77\% share of the crop is expected by 2030 . Ericcson et al. [35] estimates needs for area biomass crops on about 2.3 million ha, assuming national energy needs in the field of biomass at the level of $370 \mathrm{PJ}$ per year at an average yield of $9 \mathrm{Mg}$ per ha and calorific value 18 GJ per $\mathrm{Mg}$. Without proper fertilization, including sewage sludge, these assumptions will be difficult to achieve.

\section{Methods of sludge application}

Land application has been the most common way to dispose of the biosolids, i.e. sewage sludge [36]. The most appropriate application method for agricultural land depends on the physical characteristics of the sludge and the soil, and the species of crops grown. Generally, land application of sewage sludge is carried out by subsurface application, vehicular surface spreading, or irrigation application. The former method of sludge application is performed by disking methods, plough furrowing, or subsurface injection. Liquid or solid fertilisers can also be injected below the soil surface tank trucks fitted with flotation tires and injection shanks. Such equipment minimises odour problems and reduces 
ammonia volatilisation by immediate mixing of soil and biosolids. Subsurface injection can be used on slopes of up to $15 \%$ and will minimise runoff from all soils. Soil incorporation of liquid sludge can be effected by ploughfurrow cover and subsurface injection. Vehicular surface spreading is accomplished usually by tank truck spreading. Surface application with its incorporation is normally limited to soils with less than a 7\% slope.

Finally, irrigation application is also undertaken by flood irrigation or spray irrigation. Irrigation systems generally should not be used to apply sewage sludge to row crops during the growing season. However, a light application to the stubble of a forage crop following harvest is acceptable. Off-site management of sewage sludge involves loading, hauling and land-applying sewage sludge at a location some distance from the treatment plant. The primary advantage of this procedure is the ability to make use of remote tracts of land that may be scattered some distance from the treatment plant.

Tanks mounted on powered chassis that are equipped with large, low-pressure tires for traversing soft ground are used most commonly for land-applying sewage sludge. The resulting rough surface may be unacceptable for subsequent land use such as grazing or haying.

\section{Trailer for land-applying sewage sludge}

Fertilisation of perennial plantations using already known devices does not guarantee optimal performance of this operation, i.e. the sewage should be applied at the proper depth and must be covered by a soil layer. These requirements are particularly important in relation to the Act on Waste Materials, of 14 December 2012 (J. of Laws, 2013, item. 21) and Regulation of Minister of Environment on communal sludge of 6 February 2015, and must use fertiliser properly prepared sludge from municipal sewage-treatment plants.

To meet the mentioned requirements Niemiec [37] developed a trailer for subsurface application of sewage sludge in plantations of energetic willow (Fig. 1). The machine is a part of fleet of agricultural machines for the establishment of plantations and the processing of woody biomass $[12,13]$. The efficiency of enrichment tract plantation depends on the proper dosage of fertilisers and fertilisation depth. Furthermore, the sewage should be immediately incorporated directly into soil and should never be seen on the surface of the field. Application of organic fertilisers with loose consistency into the soil to the desired depth is the main advantage of the trailer. The sewage sludge is supplied to the vicinity of the plant root without its damaging, which facilitates the absorption of nutrients by plants. The device (Fig. 1) is mounted on the standard currently used manure fertiliser as a separate module, without the need for significant customisation. According to the concept, it is assumed that the device is mounted to a manure spreader and has its own hydraulic system for setting its working position in relation to the ground. The device is equipped with three sections of fertiliser application with a spacing of $0.75 \mathrm{~m}$, which corresponds to a typical system of willow planting. a)

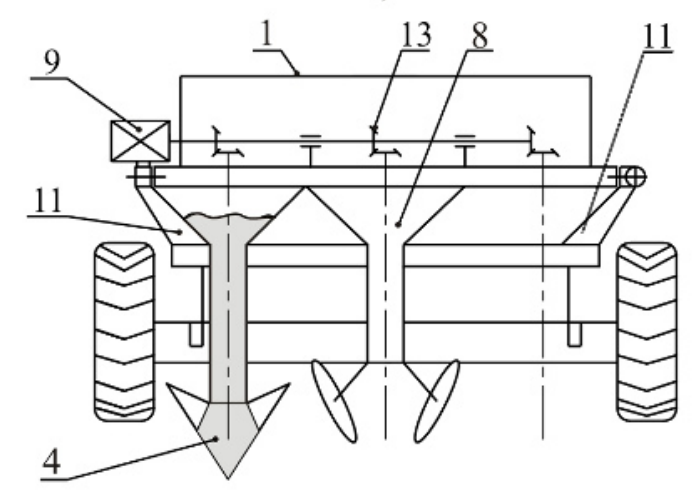

b)

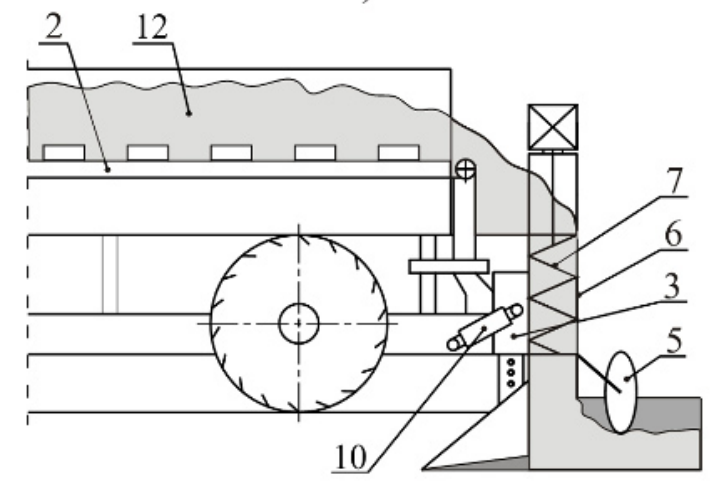

Figure 1. Schematic of the back (a) and side (b) view of the conceptual trailer for subsurface application of loose organic and mineral fertilisers [37]: 1 - trailer, 2 - base frame, 3 - beam, 4 - disk coulter, 5 - ridging plough, 6 - cylindrical housing of screw conveyor, 7 - screw conveyor, 8 - loading chamber, 9 hydraulic engine, 10 - hydraulic cylinder, 11- arm, 12 fertiliser, 13 - bevel gear.

The prototype of the trailer (Fig. 2) for subsurface application of sewage sludge into soil was developed at Rzeszow University of Technology in cooperation with "R\&D Centre Inventor Sp. z o.o." and "SIPMA S.A", both in Lublin. The device is attached to the trailer. The disc coulters are fastened to the support frame. The disk ridging ploughs are placed behind the disc coulters. Cylindrical housings with the screw conveyors working inside are coupled to the frame of the device. In the upper part of the screw conveyors, the bevel gears driven via a reducer by the hydraulic motor are mounted. The hydraulic system of the trailer is supplied from the tractor. Each of the three screw conveyors alternatively may be individually equipped with a hydraulic motor powered from the tractor's hydraulic system. The location of the disc coulters relative to the frame is established discretely by a mechanical blockage. However, the location of the disc coulters in relation to the frame can be set continuously by the hydraulic system. The arms coupled to a hydraulic cylinder are used to set the machine in the transport position. The depth of the grooves for buckfilling the fertiliser in furrows is set by changing the position of the disc coulters and ridging ploughs in relation to the ground. During the machine operation, the weight of the manure in the transport chamber is moved toward the application area using the floor conveyor. The fertiliser is transported using 
the screw conveyors to the grooves in the soil. Filled with sewage sludge, the grooves are then buckfilled by the ridging ploughs (Fig. 3).

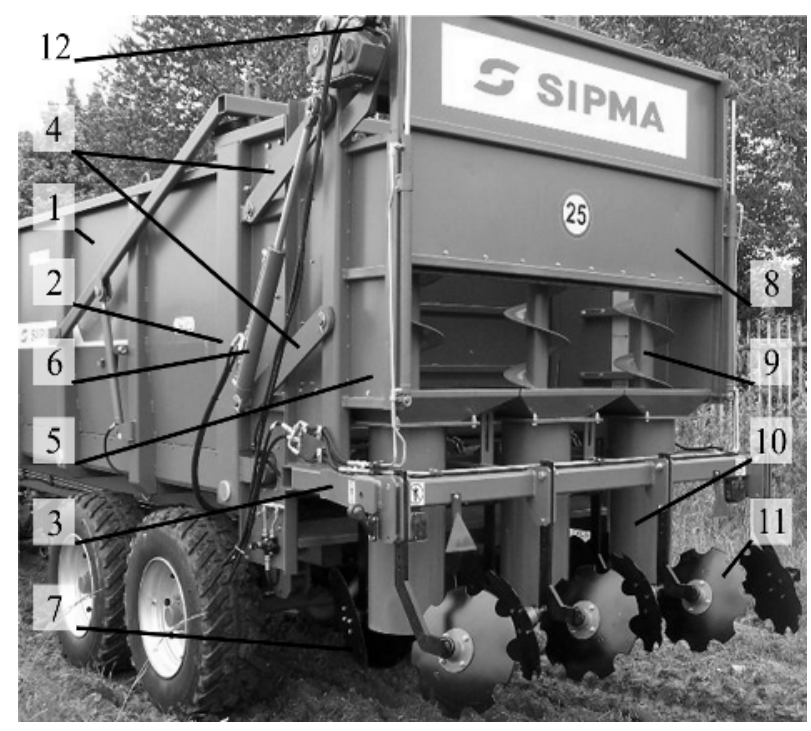

Figure 2. Prototype of device for subsurface application of loose organic and mineral fertilisers manufactured by SIPMA S.A.: 1 - trailer, 2 - base frame, 3 - beam, 4 - arms, 5 - loading chamber, 6 - hydraulic cylinder, 7 - disc coulter, 8 - flap, 9 screw conveyor, 10 - cylindrical housing of screw conveyor, 11 - ridging plough, 12 - hydraulic engine.

Field tests were carried out on an experimental plantation of energetic plants (Fig. 4), in cooperation with the sewage-treatment plant in Świlcza (Poland). Municipal sewage sludge from the hygienisation line was transported directly on a trailer. The tests of the prototype of the trailer confirmed the correct functional features of the system.

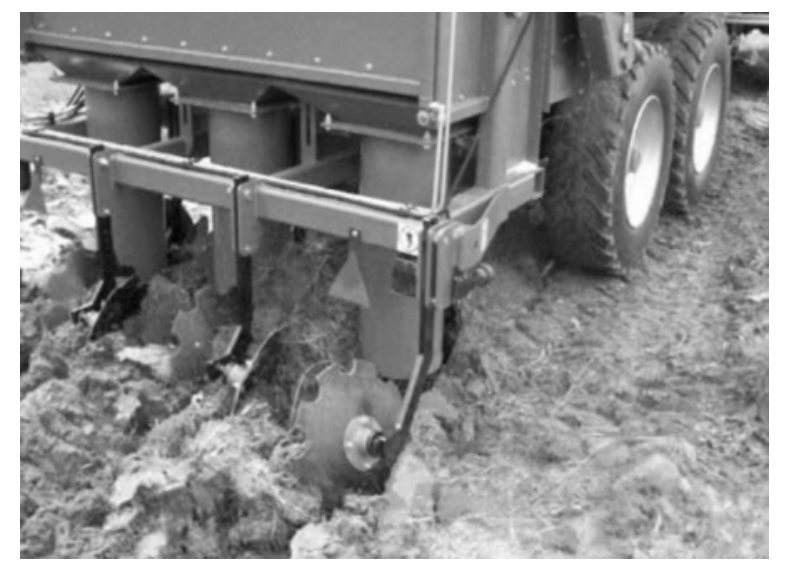

Figure 3. Application of sewage sludge into the soil subsurface.

Subsurface application of sewage sludge with the use of the device for injection dosage of mineral and organic fertilizers is the ideal solution for small and medium wastewater treatment plants. Owing to the high prices of thermal sludge utilization methods, the aforementioned technique is the most economically justified. The sewage sludge can be applied into soil in spring to assure plants nutrients necessary to their growth. Generally, using developed trailer we can apply the sewage sludge through the all year, excluding winter months due to soil freezing.

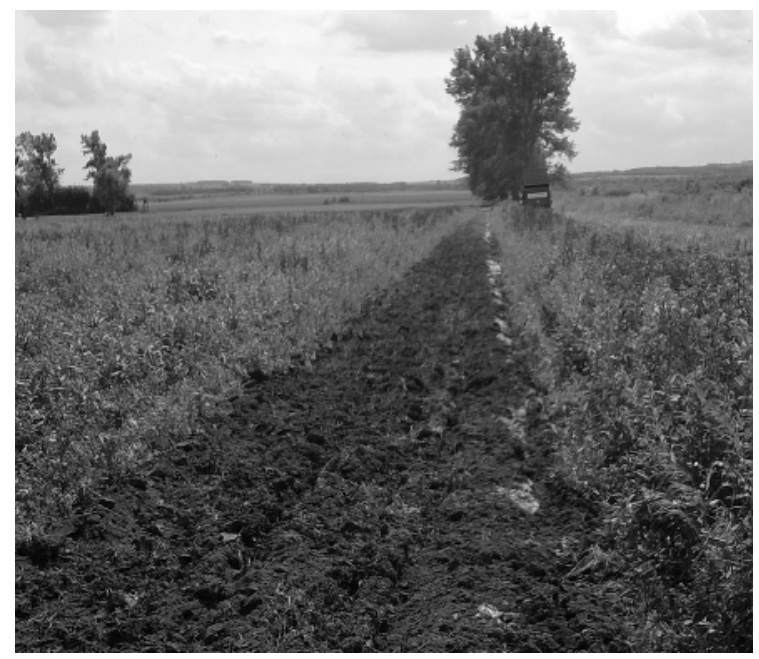

Figure 4. View of the willow plantation after subsurface application of sewage sludge.

The dosage of properly treated sewage sludge by subsurface application into soil could be an alternative method to the popular in recent years sludge hygienisation with lime and the production of granular fertilizer. The liming of sewage sludge requires the modernization of treatment plants and equipment installation, the cost of which can reach even 500,000 PLN. The process of hygienisation and agglomeration demands a dose of hydrated lime ranging from $0.15-0.25$ $\mathrm{kg}$ per $\mathrm{kg}$ of sewage sludge d.m. which could result in subsequent sterilization and soil degradation. Assuming the price of highly reactive lime ranging from 290-350 PLN per Mg of lime, additional costs of approximately 30,000-100,000 PLN per year are generated for middle-sized sewage-treatment plant.

\section{Effect of sewage sludge on soil}

Sewage sludge from waste-water treatment plant in Swilcza is applied into the soil using the prototype of trailer (Fig. 2). The experimantal plantation (Fig. 5) is located about 2 kilometers from waste-water treatment plant. The current total willow plantation area is at most 30 ha. Different species of energetic plants are grown on the plantation. However, in this paper the results of soil monitoring before and after sewage sludge application are presented for energetic willow. The potential of biosolids for contaminating soils with heavy metals has caused great concern about their application in agricultural practices. Heavy metals most commonly found in sewage sludges are $\mathrm{Cd}, \mathrm{Cr}, \mathrm{Cu}, \mathrm{Ni}$, $\mathrm{Pb}$ and $\mathrm{Zn}$, and the metal concentrations are governed by the type of process employed during the sewage treatment.

Sewage sludge was characterized by high volatility in terms of quality (dry matter, nitrogen, phosphorus) and heavy metal content (Tables 2 and 3). Sewage sludge meets sanitary requirements and legal requirements and can be used for agricultural purposes on medium and/or heavy lands. Monitoring the quality of the soil was carried out in the plantation of energetic willow (1-9 in Fig. 5). The samples of soil were collected according to the standard PN-R-04031:1997. To determine the basic 
parameters to establish initial and final concentrations the samples were taken from the same place.

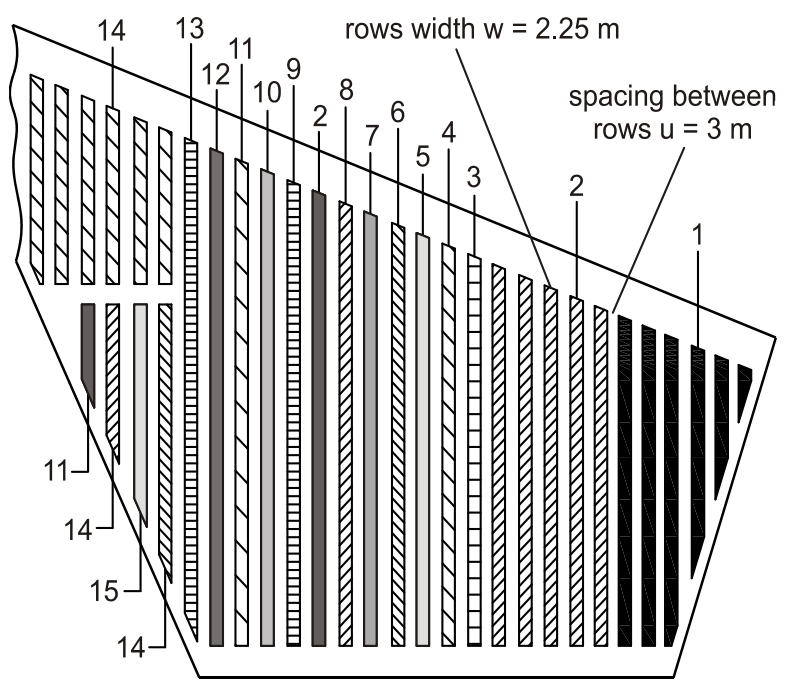

Figure 5. The view of the species arrangement in experimental plantation of energetic plants: 1-9 - genetypes of energetic willow: RF4, RM1, RZ47, RZ52, FR, M, RFM3, RFM2, RZ52, respectively; 10 - mix of willow genotypes, 11 - robinia and mix of willow genotypes, 12 - robinia, 13 - mix of willow genotypes and Rosa multiflora, 14 - mix of willow genotypes, 15 - paulownia.

Table 2. Characteristic of sewage sludge used in investigations.

\begin{tabular}{|c|c|c|c|c|c|c|c|}
\hline \multirow{2}{*}{ Parameter } & \multicolumn{7}{|c|}{ Conce ntration in se wage sludge } \\
\cline { 2 - 8 } & DM & OM & TP & TN & $\begin{array}{c}\text { N- } \\
\text { NH }\end{array}$ & Ca & Mg \\
\hline Average & 31.7 & 39.2 & 0.92 & 2.64 & 0.11 & 22.0 & 0.28 \\
\hline Minimum & 16.4 & 19.4 & 0.22 & 1.0 & 0.10 & 11.9 & 0.15 \\
\hline Maximum & 61.2 & 49.7 & 1.55 & 3.76 & 0.12 & 33.6 & 0.35 \\
\hline CV & 0.80 & 0.44 & 0.62 & 0.49 & 0.10 & 0.44 & 0.34 \\
\hline SD & 25.53 & 17.16 & 0.57 & 1.30 & 0.01 & 9.66 & 0.09 \\
\hline $\begin{array}{c}15^{\text {th }} \\
\text { percentile }\end{array}$ & 16.76 & 28.13 & 0.46 & 1.54 & 0.1 & 14.0 & 0.20 \\
\hline $\begin{array}{c}85^{\text {th }} \\
\text { percentile }\end{array}$ & 48.12 & 49.34 & 1.38 & 3.69 & 0.11 & 30.1 & 0.35 \\
\hline
\end{tabular}

DM - dry mass, OM-organic matter, TP - total phosphorus, TN -total nitrogen, $\mathrm{N}-\mathrm{NH}_{4}$ - ammonium nitrogen, $\mathrm{CV}$ - coefficient of variation, $\mathrm{SD}$ - standard deviation

Monitoring the quality of the soil in plantation of energetic willow showed no negative effect of the application of sewage sludge on the soil quality (Table 4).

Although $\mathrm{Cu}, \mathrm{Ni}, \mathrm{Pb}$ and $\mathrm{Zn}$ concentrations increased with the addition of sewage sludge, the concentration of heavy metals are within the limit values for soils of the urban areas defined in the Regulation of the Minister of Environment dated 09 September 2001 on Soil Quality Standards and Quality Standards of Soil (J. of Laws, 2002, No 165, item 1359). Proper agricultural practices ensure the adequate development of energy crops fertilized with sewage sludge. Heavy metals introduced into the soil with sewage sludge as a result of good mixing and distribution on the surface of the whole area undergo bioaccumulation in energy plants.

Table 3. Heavy metals concentration in sewage sludge used in investigations.

\begin{tabular}{|c|c|c|c|c|c|c|c|}
\hline \multirow{2}{*}{} & \multicolumn{7}{|c|}{$\begin{array}{c}\text { Concentration in sewage sludge } \\
\text { [mg per kg of dry mas s }\end{array}$} \\
\cline { 2 - 8 } & $\mathbf{C d}$ & $\mathbf{C u}$ & $\mathbf{N i}$ & $\mathbf{P b}$ & $\mathbf{Z n}$ & $\mathbf{H g}$ & $\mathbf{C r}$ \\
\hline Average & 2.5 & 77.6 & 6.1 & 3.67 & 358.9 & 0.149 & 8.03 \\
\hline Minimum & 0.3 & 19.3 & 2.6 & 2.5 & 70.7 & 0.005 & 3.37 \\
\hline Maximum & 8.8 & 122.0 & 9.7 & 11.2 & 604.0 & 0.27 & 11.5 \\
\hline $\mathrm{CV}$ & 1.65 & 0.56 & 0.47 & 0.49 & 0.62 & 0.80 & 0.44 \\
\hline SD & 4.2 & 43.32 & 2.88 & 3.67 & 221.9 & 0.119 & 3.5 \\
\hline $\begin{array}{c}15^{\text {th }} \\
\text { percentile }\end{array}$ & 0.38 & 44.55 & 4.18 & 4.68 & 191.0 & 0.048 & 5.25 \\
\hline $\begin{array}{c}85^{\text {th }} \\
\text { percentile }\end{array}$ & 5.11 & 109.2 & 8.12 & 10.12 & 522.2 & 0.248 & 10.7 \\
\hline
\end{tabular}

Table 4. Characteristic of agricultural soil before and after subsurface application of sewage sludge.

\begin{tabular}{|c|c|c|c|}
\hline \multirow{2}{*}{ Element } & \multicolumn{2}{|c|}{$\begin{array}{l}\text { Average } \pm \text { SD accumulation of heavy } \\
\text { metals [mg per kg of dry mass] }\end{array}$} & \multirow{2}{*}{$\begin{array}{c}\text { The limit } \\
\text { values in the } \\
\text { soil }\end{array}$} \\
\hline & $\begin{array}{l}\text { Before application } \\
\text { of sewage sludge }\end{array}$ & $\begin{array}{l}\text { After application } \\
\text { of sewage sludge }\end{array}$ & \\
\hline $\mathrm{Cd}$ & not tested & $0.82 \pm 0.212$ & 2.0 \\
\hline $\mathrm{Cu}$ & $17.83 \pm 0.27$ & $21.47 \pm 9.26$ & 50.0 \\
\hline $\mathrm{Ni}$ & $21.41 \pm 0.33$ & $29.93 \pm 12.28$ & 35.0 \\
\hline $\mathrm{Pb}$ & $48.48 \pm 0.47$ & $31.53 \pm 10.93$ & 60.0 \\
\hline $\mathrm{Zn}$ & $48.65 \pm 0.44$ & $58.67 \pm 15.66$ & 120.0 \\
\hline $\mathrm{Hg}$ & not tested & $0.117 \pm 0.040$ & 1.2 \\
\hline $\mathrm{Cr}$ & $78.17 \pm 1.108$ & $29.50 \pm 9.06$ & 75.0 \\
\hline
\end{tabular}

\section{Summary and conclusions}

The expanding acreage of energetic plants threatens traditional crops intended for food production. One of many ways to increase the acreages of energetic plants is the management of increasing areas of idle land, wasteland, or areas hitherto unused for agriculture. This is related to the potential use of sewage sludge for fertilisation.

Municipal sewage sludges from biological treatment processes require stabilisation and hygienisation. Prepared in this way, the sewage sludge used as soil fertiliser is free from any health risks. The presented 
innovative device for subsurface application of organic fertilisers ensures the compliance with both legal and technological requirements of agricultural use of municipal sewage sludge, and the requirements of the Act of 6 September 2001 on Road Transport (J. of Laws, 2001, No 125, item 1371, as amended).

The experimental investigations of the influence of sewage sludge on the quality of the soil were carried out in experimental plantation of energetic plants located in Świlcza. Monitoring the quality of the soil showed no singificant increase of the heavy metals concentration after subsurface application of sewage sludge in experimental plantation of energetic willow. The results of the present study indicate that the addition of sewage sludge does not imply environmental risks, offering a disposal of sewage sludge from sewage-treatment plant.

\section{References}

1. S.R. Smith, Philos. T. R. Soc. A, 367, 4005 (2009)

2. A. Jama, W. Nowak, Pol. J. Agron., 9, 3 (2012)

3. K.L. Perttu, J. Sustain. For., 5, 32 (1993)

4. J. Wieczorek, K. Frączek, J. Ecol. Eng., 14, 36 (2013)

5. A. Jama-Rodzeńska, J. Bocianowski, W. Nowak, D. Ciszek, K. Nowosad, Ecol. Eng., 87, 212 (2015)

6. S. Werle, Ecol. Chem. Eng. S. 22, 459 (2015)

7. R. Vaca, J. Lugo, R. Martínez, M.V. Esteller, H. Zavaleta, Rev. Int. Contam. Ambie., 27, 303 (2011).

8. E. Wołejko, U. Wydro, A. Butarewicz, T. Łoboda, Env. Prot. Eng., 39, 67 (2013)

9. M.A. Özyazici, Eurasian J. Soil Sci., 2, 35 (2013).

10. S.P. McGrath, F.J. Zhao, S.J. Dunham, A.R. Crosland, K. Coleman, J. Env. Quality, 29, 875 (2000).

11. X. Hao, C. Chang, Agr. Ecosyst. Env. 94, 89 (2003)

12. T. Trzepieciński, F. Stachowicz, W. Niemiec, L. Kępa, M. Dziurka, Croat. J. For. Eng., 37, 185 (2016)

13. W. Niemiec, F. Stachowicz, T. Trzepieciński, J. Ecol. Eng., 14, 12 (2013)

14. E. Klang-Westin, J. Errikson, Plant Soil., 249, 127 (2003)

15. J. Bieniek, A. Żołnierz-Rusinek, Agric. Eng., 4, 111 (2008)
16. A. Sieciechowicz, Z. Sadecka, S. Myszograj, M. Suchowska-Kisielewicz, Civ. Env. Eng. Report., 12, 69 (2014)

17. D. Lazdina, A. Lazdinš, Z. Karinš, V. Kāposts, J. Env. Eng. Landscape Manag., 15, 105 (2007)

18. P. Vervaeke, F. Navez, J. Martin, F.M.G Tack, M.G. Verloo, N. Lust, Workshop: Phytoremediation of Toxic Metals, June 12-15, Stockholm, Sweden (2003).

19. M. Labrecque, T.I. Teodorescu, S. Daigle, Biomass Bioenerg., 12, 409 (1997)

20. C. Rosik-Dulewska, S. Oleszek-Kudlak, Postępy Nauk Rolniczych, 5, 47 (2002)

21. K. Gondek, B. Filipek-Mazur, Acta Agrophys., 8, 83 (2006)

22. A. Jama, W. Nowak, Pol. J. Agron., 9, 3 (2012)

23. M. Labrecque, T.I. Teodorescu, For. Ecol. Manag., 150, 223 (2001)

24. C.B. Rizzardini, D. Goi, Sustainability, 6, 2424 (2014)

25. P. Soler-Rovira, J. Soler-Soler, J. Soler-Rovira, A. Polo, Fert. Res., 43, 173 (1995)

26. C.D. Tsadilas, T. Masti, N. Barbayiannis, D. Dimoyiannis, Commun. Soil Sci. Plant Anal., 26, 2603 (1995)

27. C.F. Tester, Soil Sci. Soc. Amer. J., 54, 827 (1990)

28. A. Henclik, J. Kulczycka, K. Gorazda, Z. Wzorek, Eng. Prot. Env., 17, 185 (2014).

29. K. Usman, S. Khan, Said Ghulam, M.U. Khan, N. Khan, M.A. Khan, S.K. Khalil, Amer. J. Plant Sci., 3, 1708 (2012)

30. R.M. Sterritt, J.N. Lester, Sci. Total Env., 16, 55 (1990)

31. R. Smith, H. Vasiloudis, Water S. A., 17, 19 (1991)

32. H. Trinidade, J. Coutinho, S. Jarvis, N. Moreira, Eur. J. Agron., 15, 281 (2001)

33. M. Labrecque, T.I. Teodorescu, S. Daigle, Plant Soil, 171, 303 (1995).

34. B. Holm, K. Heinsoo, Biomass Bioenerg., 57, 126 (2013).

35. K. Ericsson, H. Rosenqvist, E. Ganko, M. Pisarek, L. Nilsson, Biomass Bioenerg., 30, 16 (2006).

36. C. Schaefer, Restor. Reclam. Rev., 5, 1 (1999)

37. W. Niemiec, Patent PL 214031 (2008) 